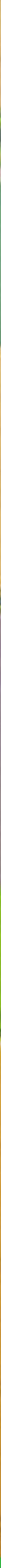

\title{
Kringloopwijzer Akkerbouw
}

Rekenmodel versie 'april 2018'

J.J. Schröder \& B. Rutgers

WAGENINGEN
WNIVERSITY \& RESEARCH 



\section{Kringloopwijzer Akkerbouw}

Rekenmodel versie 'april 2018'

J.J. Schröder \& B. Rutgers

Dit onderzoek is in opdracht van Brancheorganisatie Akkerbouw uitgevoerd door de Stichting Wageningen Research (WR), business unit Agrosysteemkunde (projectnummer BOA 17035).

WR is een onderdeel van Wageningen University \& Research, samenwerkingsverband tussen Wageningen University en de Stichting Wageningen Research.

Wageningen, april 2018

Rapport WPR-797 
Schröder, J.J. \& B. Rutgers, 2018. Kringloopwijzer Akkerbouw; Rekenmodel versie 'april 2018'. Wageningen Research, Rapport WPR-797. 20 blz.; 5 fig.; 0 tab.; 3 ref.

Dit rapport is gratis te downloaden op https://doi.org/10.18174/446740

De KringloopWijzer Akkerbouw is een rekeninstrument voor gebruik op PC's dat op basis van ingevoerde bedrijfsgegevens van, onder meer, de bouwplansamenstelling en (kunst)mestgiften, een schatting maakt van de tekorten dan wel overschotten van stikstof, fosfaat en organische stof en de emissies die daarmee verbonden zijn. Om die schatting te kunnen maken, kan de KringloopWijzer gebruik maken van gedocumenteerde opbrengstgegevens en forfaitaire nutriëntengehaltes of, naar wens, de afvoer van nutriënten schatten op basis van de omvang, aard en methode van bemesting. Dit rapport beschrijft de aanleiding voor het ontwikkelen van de KringloopWijzer, de opbouw van de invoer- en uitvoerschermen en de achterliggende rekenregels tussen die beide. Het rapport eindigt met een inventarisatie van denkbare verbeterpunten en schetst op welke wijze de KringloopWijzer in de praktijk stap voor stap getest kan worden.

Trefwoorden: akkerbouw, bemesting, overschot, emissies, nitraat, fosfaat, organische stof, broeikasgassen

(C) 2018 Wageningen, Stichting Wageningen Research, Wageningen Plant Research, Business unit Agrosysteemkunde, Postbus 16, 6700 AA Wageningen; T 03174807 00; www.wur.nl/plant-research

KvK: 09098104 te Arnhem

VAT NL no. 8113.83.696.B07

Stichting Wageningen Research. Alle rechten voorbehouden. Niets uit deze uitgave mag worden verveelvoudigd, opgeslagen in een geautomatiseerd gegevensbestand, of openbaar gemaakt, in enige vorm of op enige wijze, hetzij elektronisch, mechanisch, door fotokopieën, opnamen of enige andere manier zonder voorafgaande schriftelijke toestemming van Stichting Wageningen Research.

Stichting Wageningen Research is niet aansprakelijk voor eventuele schadelijke gevolgen die kunnen ontstaan bij gebruik van gegevens uit deze uitgave.

Rapport WPR-797

Foto omslag: Shutterstock 


\section{Inhoud}

Woord vooraf $\quad 5$

$\begin{array}{ll}\text { Samenvatting } & 7\end{array}$

$\begin{array}{llr}1 & \text { Inleiding } & 9\end{array}$

$2 \quad$ Opzet KringloopWijzer $r$

2.1 Dashboard 11

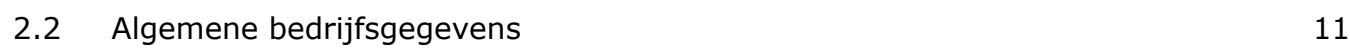

2.3 Gewassen en bemesting 12

2.4 Berekeningen $\quad 14$

$\begin{array}{lll}2.5 & \text { Uitvoer } & 15\end{array}$

$\begin{array}{llr}3 & \text { Praktijktest } & 17\end{array}$

$\begin{array}{llr}4 & \text { Discussie } & 18\end{array}$

$\begin{array}{lr}\text { Literatuur } & 19\end{array}$ 



\section{Woord vooraf}

Het voorliggende rapport beschrijft de aanleiding, opbouw en denkbare stappen bij de uitrol van de KringloopWijzer Akkerbouw. De KringloopWijzer Akkerbouw is een rekeninstrument voor gebruik op PC's dat op basis van ingevoerde bedrijfsgegevens over onder meer de bouwplansamenstelling en (kunst)mestgiften een schatting maakt van de tekorten dan wel overschotten van stikstof, fosfaat en organische stof en de emissies die daarmee verbonden zijn. Wij danken de Brancheorganisatie Akkerbouw (BOA) voor de opdracht om de KringloopWijzer Akkerbouw te ontwikkelen. Daarbij willen we in het bijzonder de Stuurgroepleden J. van Wenum (LTO), G. Dubben (NAV), H. Kager (v/h LTO), M. Heijmans (LTO) en E. de Jongh (BOA) bedanken. Ook zijn we de leden van de LTO-NAV Commissie Bemesting Akkerbouw en Vollegrondsgroenten erkentelijk voor het commentaar dat ze op een eerste versie van de KringloopWijzer gaven. Wij hopen dat het rekeninstrument zijn nut kan gaan bewijzen in de praktijk, te beginnen bij een testgroep van praktiserende akkerbouwers.

Jaap Schröder en Ben Rutgers 


\section{Samenvatting}

De KringloopWijzer Akkerbouw is een rekeninstrument voor gebruik op PC's dat op basis van ingevoerde bedrijfsgegevens van, onder meer, de bouwplansamenstelling en (kunst)mestgiften, een schatting maakt van de tekorten dan wel overschotten van stikstof, fosfaat en organische stof en de emissies die daarmee verbonden zijn. Om die schatting te kunnen maken, kan de KringloopWijzer gebruik maken van gedocumenteerde opbrengstgegevens en forfaitaire nutriëntengehaltes of, naar wens, de afvoer van nutriënten schatten op basis van de omvang, aard en methode van bemesting. Dit rapport beschrijft de aanleiding voor het ontwikkelen van de KringloopWijzer, de opbouw van de invoer- en uitvoerschermen en de achterliggende rekenregels tussen die beide. Het rapport eindigt met een inventarisatie van denkbare verbeterpunten en schetst op welke wijze de KringloopWijzer in de praktijk stap voor stap getest kan worden. 


\section{$1 \quad$ Inleiding}

In bepaalde situaties (gewassen, percelen, bedrijven, regio's) gaat de teelt van gewassen gepaard met te hoge emissies van stikstof $(N)$ in de vorm van nitraat. Dat vereist maatregelen om alsnog aan de Europese Nitraatrichtlijn te kunnen voldoen. Lidstaten leggen die maatregelen vast in vierjaarlijkse Actieprogramma's. Maatregelen bestaan onder meer uit een beperking van mest- en kunstmestgiften, in een aantal gevallen tot aan een niveau lager dan de adviesgiften. De maatregelen hebben een generiek karakter en doen daarmee noch landbouwkundig, noch milieukundig recht aan iedere situatie: ze kloppen slechts gemiddeld omdat ze soms te mild, soms te streng zijn. Dat kan ten koste gaan van de milieukwaliteit maar ook ten koste van opbrengst en inkomen op de korte en lange termijn. Actieprogramma's bieden ruimte om alternatieve maatregelen te ontwerpen, te toetsen en in te voeren en op die manier N-giften in de vorm van mest en kunstmest, zij het onder voorwaarden, minder te hoeven beperken.

Voor de melkveehouderijsector heeft Wageningen Universiteit en Research (WUR) het instrument KringloopWijzer (KLW) ontwikkeld. Het is een rekenmodel dat op basis van veestapelsamenstelling, gerealiseerde melkproductie, en de aankoop van (kunst)mest- en voer, een schatting maakt van de onttrekkingen van stikstof $(\mathrm{N})$ en fosfaat $(\mathrm{P})$ door gewassen en berekent wat de bodemoverschotten of -tekorten zijn van $\mathrm{N}$, van $\mathrm{P}$ en van organische stof. De KLW maakt ook een schatting van de emissies van broeikasgassen, ammoniak en nitraat en toont aan of het desbetreffende bedrijf op grond van de gerealiseerde productie meer of minder (kunst)mest zou kunnen gebruiken binnen milieurandvoorwaarden. Op dit moment wordt binnen de melkveehouderijsector nagegaan of de invoergegevens van deze KLW voldoende geborgd kunnen worden om wettelijk toegestane (kunst)mestgiften bedrijfspecifieker te maken. Sinds 2016 is de bovengenoemde KLW ook geschikt gemaakt voor melkveebedrijven met een tak akkerbouw, althans voor een beperkt aantal akkerbouwgewassen. Het 'dashboard' van de KLW Melkveehouderij laat echter niet toe om het dieronderdeel 'uit' te zetten en de KLW op die manier voor een puur akkerbouwbedrijf te gebruiken. Ook is het aantal akkerbouwgewassen vooralsnog beperkt en ontbreekt de mogelijkheid om alternatieve scenario's op een overzichtelijke manier met elkaar te vergelijken.

Akkerbouwers hebben aangegeven behoefte te hebben aan een KLW-achtig instrument hoewel op akkerbouwbedrijven, anders dan op een melkveebedrijf, maar een deel van de mineralenkringloop plaatsvindt. De overeenkomst tussen beide typen bedrijven zit dan ook niet zozeer in het kringloopaspect maar in de wens om verliezen te beperken met behoud van opbrengst. In de aanloop naar de ontwikkeling van een dergelijk instrument is gebleken dat sommige akkerbouwers geen goed beeld hebben van wat een KLW is. Zo is de KLW geen instrument om de bodemkwaliteit in de breedste zin te onderbouwen en sturen. Wel maakt de KLW een berekening van de bedrijfsspecifieke organische stof balans, maar daar houdt het wat betreft bodemkwaliteit mee op. Ook is het een misverstand om te veronderstellen dat het eigenhandig invoeren van gegevens in een KLW, voldoende basis zal vormen voor het mogen toedienen van verruimde $\mathrm{N}$-giften. Dat zal alleen op basis van borgbare gegevens het geval kunnen zijn, net zoals in de melkveehouderij. Dat betekent allerminst dat een KLW niet geschikt is om zelf allerlei gegevens in te voeren. In dat geval heeft de KLW als doel om een ondernemer alternatieve maatregelen te laten verkennen en zo te ontdekken of die alternatieven in beginsel in aanmerking kunnen komen als een borgbare alternatieve maatregel die af zou kunnen wijken van het stelsel van generieke maatregelen (gebruiksnormen, gebruiksvoorschriften). Alternatieve maatregelen kunnen betrekking hebben op de gewaskeuze of op de aard, omvang en wijze van bemesten. Bezien vanuit het voorgaande moet dus een onderscheid gemaakt worden tussen de KLW-functie 'onderbouwing van een alternatieve maatregel' ('opgave modus') en de KLW-functie 'verkenning van een maatregel' ('prognose modus'). Een instrument in voornoemde zin (Figuur 1) is inmiddels ontwikkeld en het onderhavige verslag beschrijft dat instrument. 


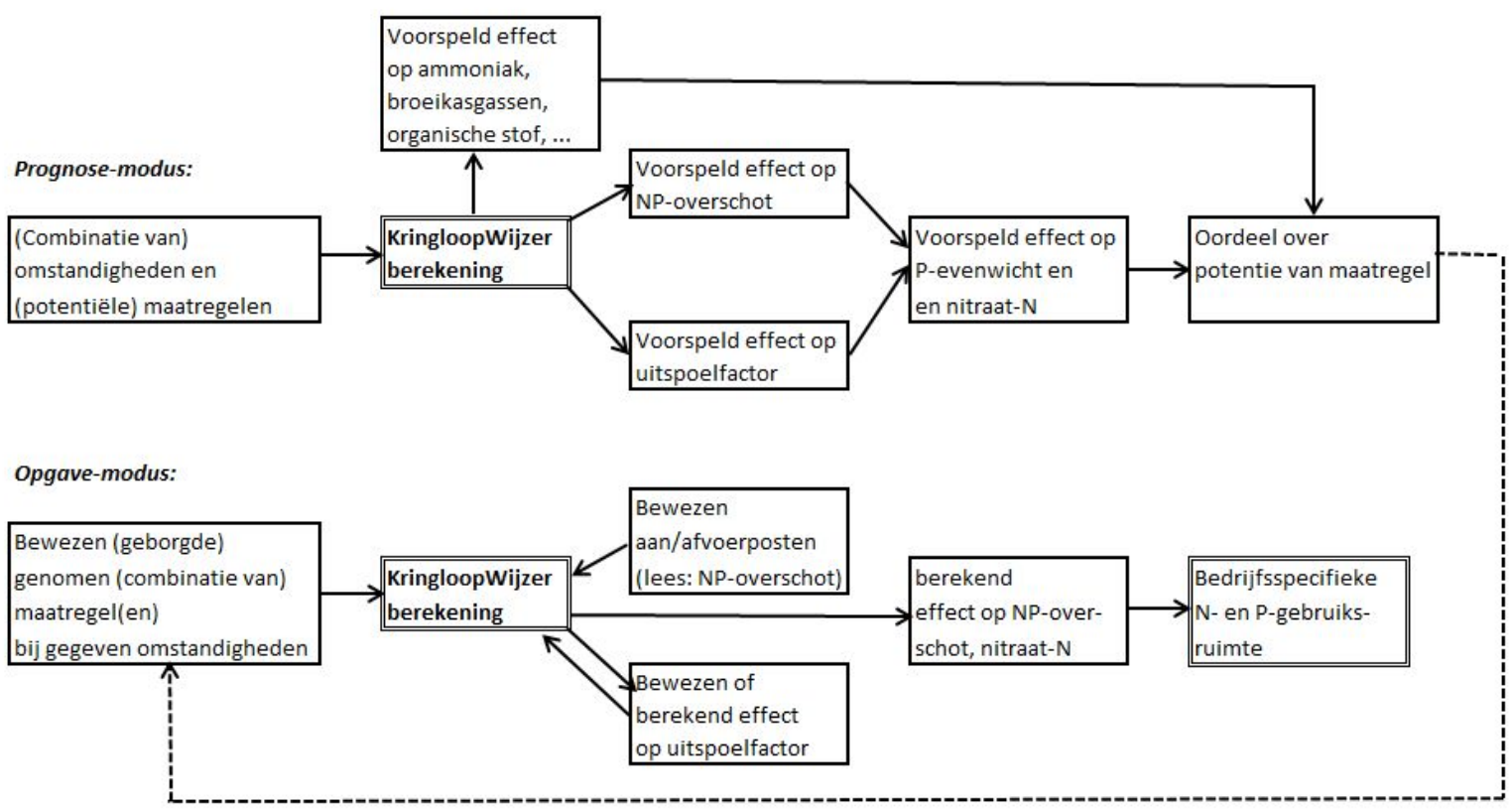

Figuur 1 De 'prognose modus' en de 'opgave modus' van een KringloopWijzer Akkerbouw 


\section{Opzet KringloopWijzer}

\section{$2.1 \quad$ Dashboard}

Bij het opstarten van de KringloopWijzer wordt een dashboard zichtbaar waarop drie gebieden onderscheiden worden: het gebied 'invoer', het gebied 'uitvoer' en het gebied 'scenario'. Binnen 'invoer' wordt een knop 'algemene bedrijfsvragen' en 'gewassen en bemesting' onderscheiden. Binnen 'uitvoer' wordt een knop 'uitvoer' en 'print in- en uitvoer' onderscheiden. Binnen het gebied 'scenario' kan naar keuze een zelf gekozen naam aan een scenario worden toegekend, kan een scenario worden 'opgeslagen', kan een bestaand scenario worden 'geladen' om er wijzigingen in aan te brengen en kunnen bestaande scenario's met elkaar worden vergeleken (Figuur 2).

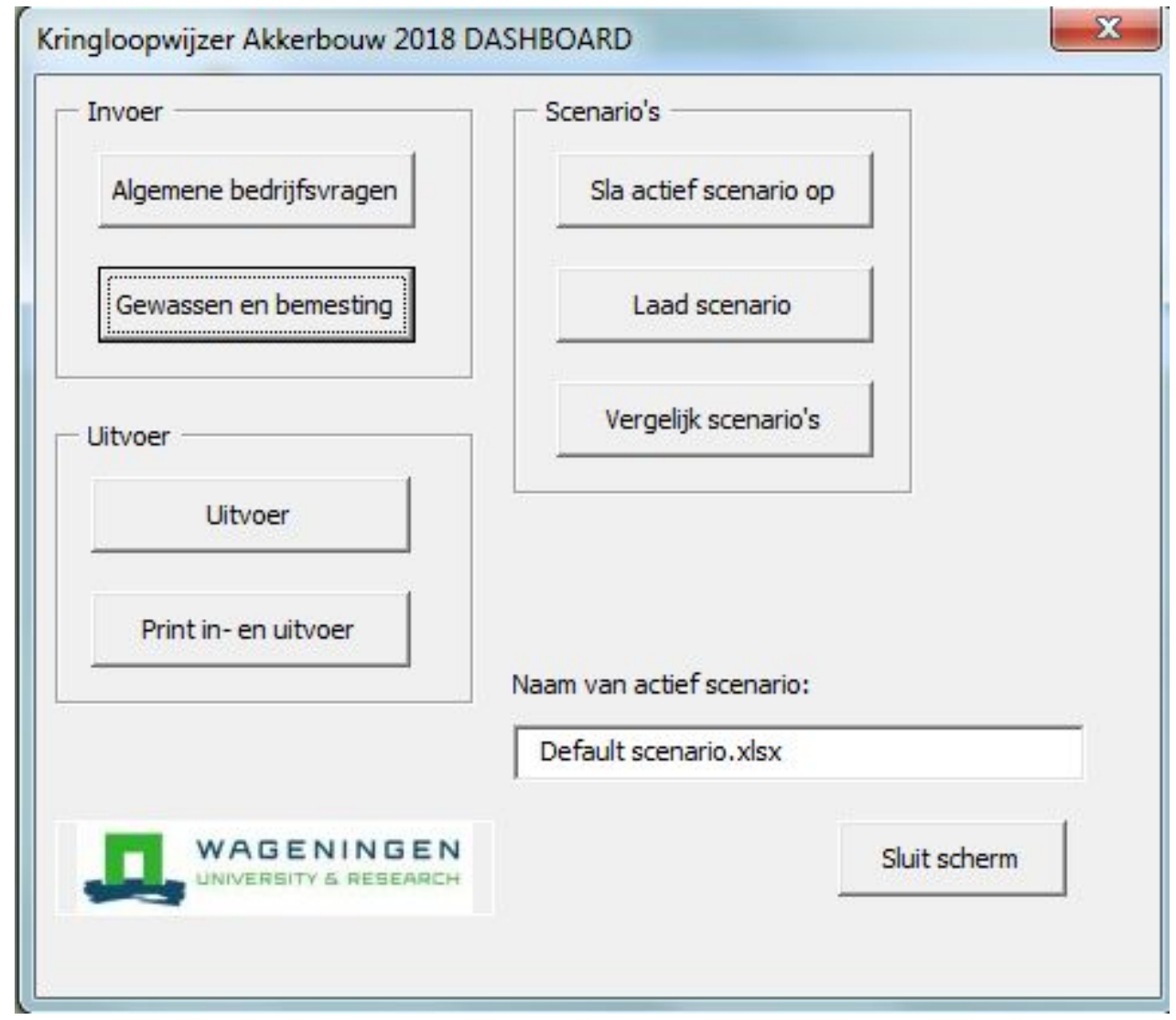

Figuur 2 Dashboard van de KringloopWijzer Akkerbouw

\subsection{Algemene bedrijfsgegevens}

Gebruikers vullen voor hun bedrijf éénmalig gegevens in die min of meer voor het bedrijf gelden (Figuur 3). Dat betreft allereerst de procentuele verdeling van het areaal over fosfaatklassen. Deze gegevens zijn nodig om de P-gebruiksnorm te bepalen en gebruikers te kunnen attenderen op onderof overschrijding van de wettelijke ruimte. Verder kan in het scherm worden aangegeven of berekeningen betrekking moeten hebben op 2018, 2019 of 2020. Dit is van belang omdat P-gebruiksnormen aan veranderingen onderhevig zullen zijn. Ook wordt hier het gemiddelde organische stofgehalte van de bouwvoor opgegeven. Dit gehalte wordt gebruikt om te schatten wat de jaarlijkse afbraak van organische stof is en welke aanvulling nodig is om het gehalte niet terug te 
laten lopen. In dit scherm wordt ook gevraagd of het bedrijf behoort tot de zand- en lössgronden van Limburg of Noord-Brabant. Dat gegeven is nodig om de wettelijk toegestane N-gebruiksnorm te bepalen. Tenslotte bestaat de optie om niet met vaste $\mathrm{N}$-gehalten in gewassen te rekenen maar met variabele. Lopend onderzoek geeft namelijk aan dat het $\mathrm{N}$-gehalte van een aantal akkerbouwgewassen lager is naarmate het opbrengstniveau hoger is.

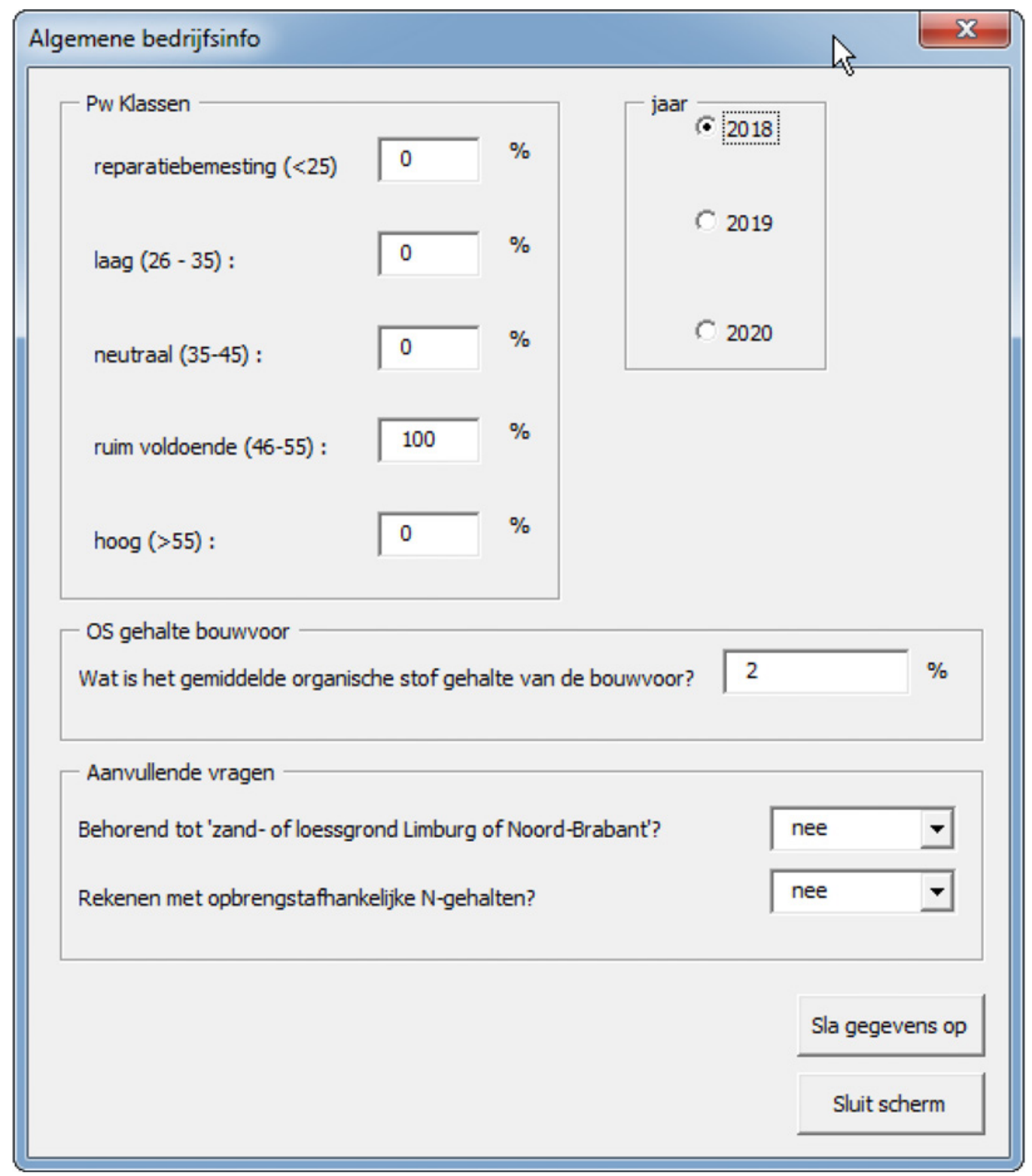

Figur 3 Invoerscherm Algemene Bedrijfsinfo

\subsection{Gewassen en bemesting}

Figuur 4 toont het invoerscherm voor gewassen en bemesting. In dat scherm wordt het bedrijf, gewas voor gewas, opgebouwd. Daarbij bestaat een keuze uit 65 gewassen, inclusief groenbemesters. In het getoonde voorbeeld is begonnen met het gewas consumptieaardappelen. Daarvan wordt om te beginnen het areaal opgegeven en het besluit om dit gewas al dan niet deels met organische mest te bemesten. De grondsoort wordt nader gespecificeerd teneinde een schatting te kunnen maken van de nitraatuitspoeling. Ook wordt gevraagd naar een schatting van de gemiddeld realiseerbare opbrengst in afwezigheid van een $\mathrm{N}$-beperking. Deze informatie wordt gebruikt om de generieke $\mathrm{N}$-responscurve van, in dit geval, consumptieaardappelen te vervangen door een curve met een meer bedrijfsspecifiek 
plafond ten behoeve van berekeningen in de 'prognose' modus (Figuur 1). Daarnaast wordt gevraagd naar de daadwerkelijk gerealiseerde opbrengst om de afvoer volgens de opgave-modus te berekenen (Figuur 1).

Vervolgens kunnen per gewas één of twee organische mestgiften gedefinieerd worden (welke mest, hoeveel, wanneer en op welke wijze). De verstekgehalten van de desbetreffende mest kunnen desgewenst overschreven worden met bedrijfsspecifieke waarden. Omdat N-beschikbaarheid voor een gewas bij rijenteelten ook bepaald wordt door de positionering ten opzichte van de rij, kan in dit scherm ook worden aangegeven of organische mest en kunstmest als rijenbemesting of volvelds worden toegediend. Dit kan consequenties hebben voor de berekende onttrekkingen in de 'prognose' modus. Op basis van de opgegeven grondsoort, regio en Pw's worden N- en P-gebruiksnormen aangeroepen en wordt de resterende kunstmest- $N$ ruimte bij het opgegeven mestgebruik berekend. Boven de één na laatste regel wordt, voortschrijdend met ieder volgend gewas dat de gebruiker aan het bedrijf toevoegt, een voortschrijdende balans van (gebruikte) gebruiksruimte bijgehouden. Die balans maakt inzichtelijk of (kunst)mestgiften verhoogd of verlaagd kunnen worden om precies aan gebruiksnormen te voldoen. Dit kan door giften ('actuele gift') aan te passen in het gewas wat op dat moment onder handen is of door terug te scrollen naar eerder gedefinieerde gewassen. Om de ingevoerde data te bewaren dient daartoe opdracht gegeven te worden ('sla deze gegevens op'). 


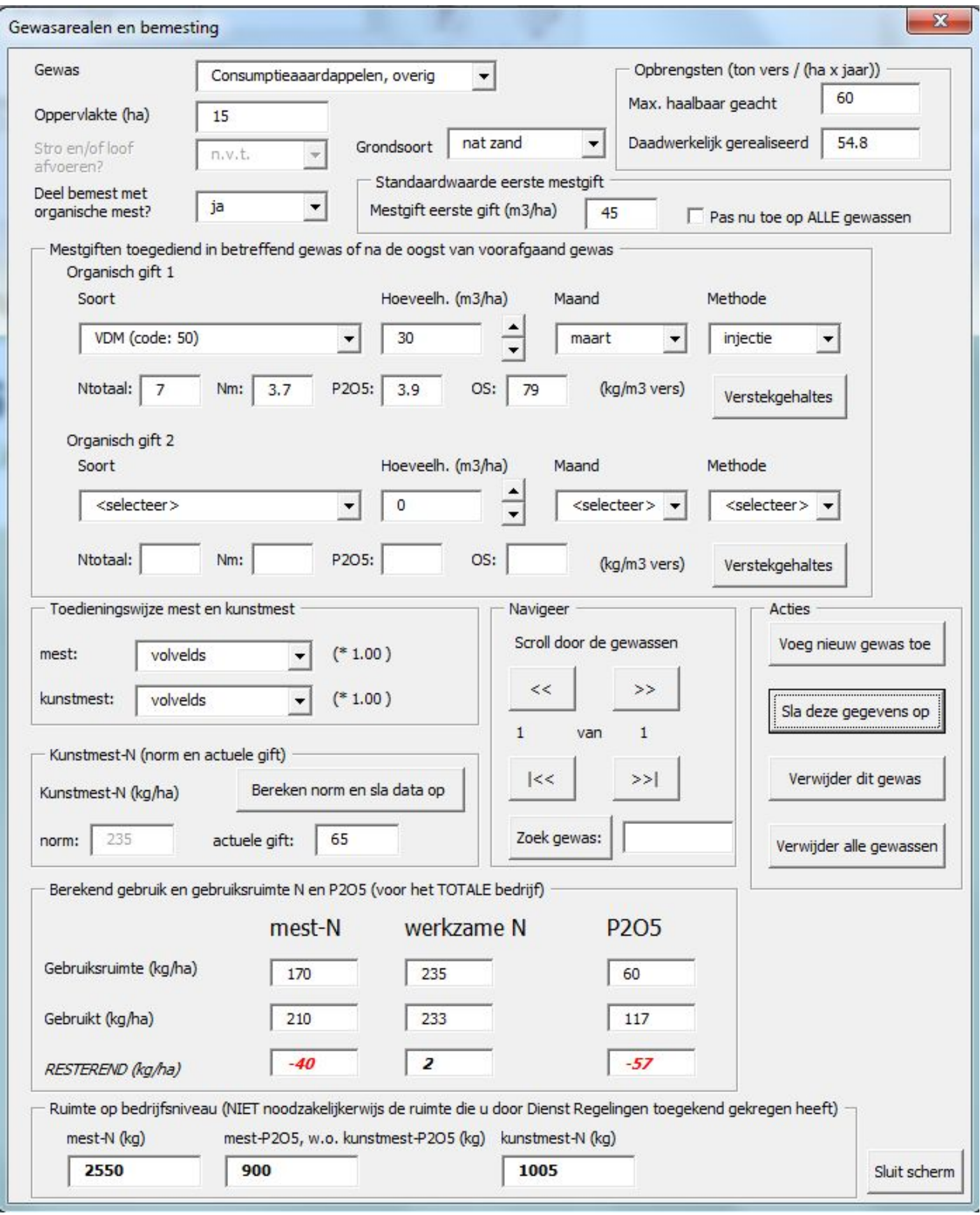

Figuur 4 Invoerscherm 'gewassen en bemesting'

\subsection{Berekeningen}

Als alle gewassen zijn ingevuld en de gegevens zijn opgeslagen, kan het scherm 'gewassen en bemesting' worden afgesloten en via het dashboard om de uitvoer gevraagd worden. Tussen invoer en uitvoer vinden berekeningen plaats om, onder meer, de aan- en afvoerbalansen van $N$, van $P$ en van organische stof op te stellen. Voor wat betreft $\mathrm{N}$ en $\mathrm{P}$ wordt daarbij twee soorten balansen gemaakt: die op basis van opgegeven gewasopbrengsten ('opgave modus') en die volgens gesimuleerde onttrekkingen ('prognose modus'). In het eerste geval worden opbrengsten vermenigvuldigd met hun forfaitaire gehalten (naar keuze met opbrengstafhankelijke $\mathrm{N}$ gehalten) en de nutriëntenafvoer en overschotten op die basis berekend. In het tweede geval worden nutriëntenafvoeren berekend op 
basis van $\mathrm{N}$-responscurves. Die responscurves zijn bedrijfsspecifiek gemaakt op basis van de opgegeven haalbaar geachte opbrengst. De aldus becijferde N-onttrekking wordt met een forfaitaire gewas-specifieke $\mathrm{P} / \mathrm{N}$ verhouding tevens vertaald in de $\mathrm{P}$-onttrekking. De $\mathrm{N}$-overschotten worden toebedeeld aan de verliesposten ammoniakvervluchtiging, nitraatuitspoeling en gasvormige verliezen in de vorm van $\mathrm{N}_{2}, \mathrm{~N}_{2} \mathrm{O}$ en NO. De berekeningen veronderstellen verder een evenwicht tussen de jaarlijkse aanvoer van $\mathrm{N}$ en $\mathrm{P}$ in organische stof en de cumulatieve jaarlijkse mineralisatie van $\mathrm{N}$ en $\mathrm{P}$ uit die organische stof (gewasresten, mestresten). De rekenregels achter de relaties tussen $\mathrm{N}$-aanvoer, $\mathrm{N}$ - en P-onttrekking en het lot van het N-overschot volgen die van het WOG 2.0 instrumentarium dat ontwikkeld werd voor het onderzoeken van equivalente maatregelen (Schröder et al., 2014).

In aanvulling op de berekeningen van de $\mathrm{N}$ - en P-overschotten wordt een organische stofbalans bijgehouden. De aanvoerposten van (effectieve) organische stof bestaan daarbij uit organische mest, en achtergelaten bijproducten waaronder stro, en wortel- en stoppelresten, inclusief die van verplichte vanggewassen (na mais op zand- en lössgrond) of vrijwillige groenbemesters. De forfaits die daarbij gebruikt worden zijn beschreven in Schröder et al. (2014). De jaarlijkse afbraak van organische stof wordt becijferd op $2 \%$ van de hoeveelheid organische stof die in de bouwvoor aanwezig is. Die hoeveelheid wordt berekend als het product van het opgegeven gehalte (gewichtsaandeel) aan organische stof, het volume van een hectare bouwvoor van $25 \mathrm{~cm}$, en het organische stofgehalteafhankelijke volumegewicht van grond.

De uitvoer maakt ook een schatting van de totale broeikasgasemissie van het bedrijf. Dit betreft directe $\mathrm{CO}_{2}$ emissies (brandstoffen) en indirecte emissies (verbonden aan het gebruik van producten). Ten behoeve van die berekeningen wordt aan ieder gewas een aantal veldwerkzaamheden toegekend zoals ploegen, zaaien en oogsten. Aan die werkzaamheden worden $\mathrm{CO}_{2}$ emissies verbonden zoals beschreven in Schröder et al. (2018). Naast de $\mathrm{CO}_{2}$ emissies ten gevolge van veldwerk vinden ook nog $\mathrm{CO}_{2}$ emissies plaats bij de fabricage en distributie van kunstmeststoffen. Ook die worden berekend. Bij deze emissies worden de emissies opgeteld in de vorm van $\mathrm{N}_{2} \mathrm{O}$ (265 $\mathrm{kg} \mathrm{CO}_{2}$ equivalenten per $\mathrm{kg}$ $\mathrm{N}_{2} \mathrm{O}$ ). Die emissies houden verband met het gebruik van organische mest en kunstmest. Bij $\mathrm{N}_{2} \mathrm{O}$ wordt eveneens een onderscheid gemaakt tussen directe emissies die aan het gebruik van $\mathrm{N}$-bronnen op het bedrijf zelf verbonden zijn, en indirecte $\mathrm{N}_{2} \mathrm{O}$ emissies die buiten het bedrijf optreden als een gevolg van naar elders uitgespoelde en elders gedeponeerde ammoniak. Ook daar worden de rekenregels gehanteerd zoals beschreven in Schröder et al. (2018). De $\mathrm{CO}_{2}$ balans wordt gecompleteerd met het saldo van de organische stofbalans: als de aanvoer van organische stof de afbraak overtreft (1 kg organische stof $=0,58 \times 44 / 12 \mathrm{~kg} \mathrm{CO}$ ), wordt de $\mathrm{CO}_{2}$-emissie lager, als de afbraak groter is wordt de emissie hoger. Dit resulteert in een netto-hoeveelheid broeikasgasemissies, uitgedrukt in $\mathrm{CO}_{2}-$ equivalenten per hectare. Op melkveebedrijven kunnen emissies voor het gemak aan de meest dominante output worden toegewezen, te weten melk. Op een akkerbouwbedrijf is dit vanwege de veelheid aan producten lastig omdat van een aantal posten niet éénduidig is aan te geven aan welk gewas ze moeten worden toegerekend.

\section{$2.5 \quad$ Uitvoer}

Figuur 5 toont het uitvoerscherm. Daarin worden invoergegevens en uitvoergegevens op bedrijfsniveau samengevat. In het onderhavige voorbeeld is sprake van een bedrijf van 15 hectare met alleen consumptieaardappelen. 


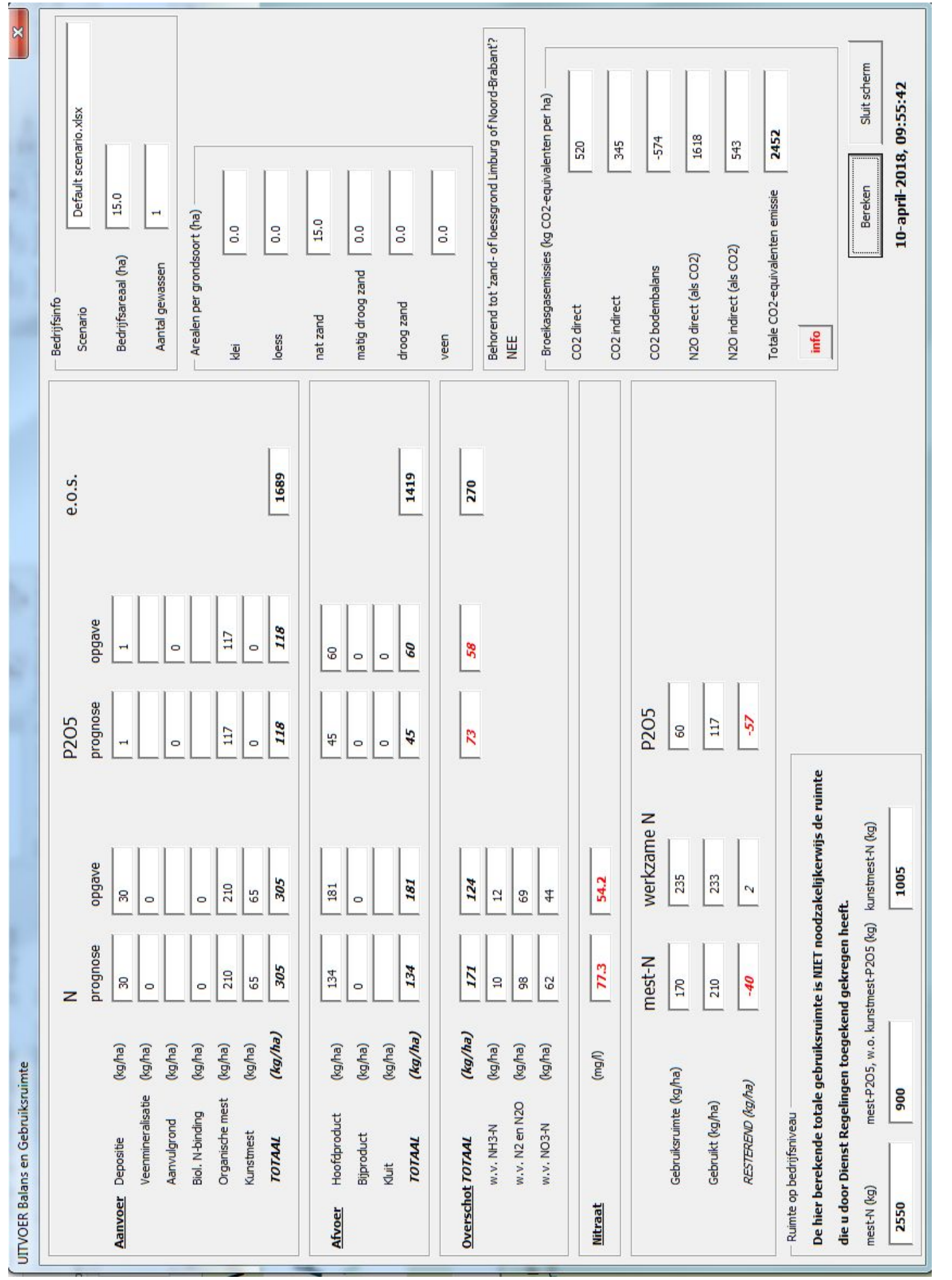

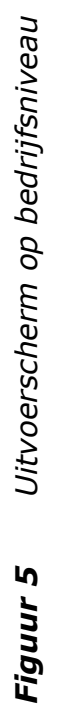




\section{$3 \quad$ Praktijktest}

De KringloopWijzer Akkerbouw is vooralsnog zeer beperkt getest. Die tests bestonden uit het invoeren door de bouwers van allerlei denkbare scenario's gevolgd door een beoordeling van de plausibiliteit van uitkomsten. Ook zijn leden van de Stuurgroep (LTO, NAV) en Begeleidingsgroep (LTO-NAV Commissie Bemesting Akkerbouw en Vollegrondsgroenten) in de gelegenheid gesteld om aanpassingen van invoer- en uitvoerschermen van een aanvankelijke versie voor te stellen. Deze aanpassingen zijn doorgevoerd in de thans voorliggende versie. Mede naar aanleiding daarvan is een aantal invoerschermen tevens voorzien van eventuele foutmeldingen en toelichtingen. De rekenregels zelf zijn bovendien ontoegankelijk gemaakt om beschadiging of aanpassing door gebruikers te voorkomen. Op grond van het voorgaande bestaat de overtuiging dat er thans een instrument voorligt dat klaar is voor een verdere beproeving in de praktijk.

Hoewel het opleidingsniveau van agrarische ondernemers gestaag toeneemt, leren ervaringen met de KringloopWijzer Melkveehouderij dat in eerste instantie een intensieve begeleiding nodig is bij zowel de invoer van gegevens als bij de interpretatie van de uitvoer. Zelfs in combinatie met een gedegen handleiding zou de KringloopWijzer bij een te snelle en brede verspreiding daarom gedoemd zijn om als hulpmiddel bij het beheer van nutriënten te mislukken. Een voorzichtige uitrol onder een beperkte groep kritische maar welwillende ondernemers lijkt een meer aangewezen werkwijze om misverstanden bij het gebruik te voorkomen en resterende tekortkomingen te verwijderen. In een eerste jaar zou gedacht kunnen worden aan groep van 5-15 ondernemers in combinatie met 2-3 voorlichters. Daarbij zou, vergelijkbaar met de totstandkoming van een project zoals Koeien en Kansen, veel aandacht geschonken moeten worden aan de selectie van deelnemers of moeten worden aangesloten bij een bestaand project waarvoor al een selectie van deelnemers heeft plaatsgevonden. Tijdens het selectieproces zou benadrukt moeten worden dat een KringloopWijzer Akkerbouw in eerste instantie is ontwikkeld om inzichten te vergroten met als toekomstige bijvangst de onderbouwing van een bepaalde bemestingsruimte. Te allen tijde moet de beeldvorming voorkomen worden dat de KringloopWijzer beoogt om telers op verzoek van overheden onder een vergrootglas te leggen. In de akkerbouw en vollegrondsgroenteteelt bestaat namelijk sterker dan in de melkveehouderij twijfel over de noodzaak van nutriëntenbeleid; de overtuiging leeft bij veel telers dat zij zelf goed weten hoeveel meststoffen voor een 'geslaagd gewas' gegeven moeten worden. Bij de selectie van deelnemers is ook speciale aandacht nodig voor het 'management van verwachtingen'. Ook dit is een ervaring die ontleend wordt aan de melkveehouderij. In die sector is de KringloopWijzer te lang 'verguld' als een instrument voor het scheppen van méér mestplaatsingsruimte. Daarbij is, achteraf bezien, te weinig onder de aandacht gebracht dat verfijningsinstrumenten ook in beeld brengen welke bodems, welke bedrijfsopzetten en welke ondernemers ónderpresteren en aldus, bij uitblijven van betere prestaties, juist strengere gebruiksnormen dan de generieke verdienen. Zonder die zogenaamde 'tweezijdigheid' zou verruiming van bemestingsruimte regionaal tot een slechter milieuresultaat leiden. Voor een succesvolle introductie van alternatieve wijzen van beoordeling, waaronder het gebruik van een KringloopWijzer, is het daarom van het grootste belang dat betrokkenen vóór aanvang van een project dienaangaande, volledige overeenstemming hebben over de referentiesituatie, dat wil zeggen het ijkpunt op basis waarvan ondubbelzinnig kan worden vastgelegd of de milieuprestaties beter of slechter geworden zijn (Schröder, 2017). Een zorgvuldig 'management van verwachtingen' heeft ook betrekking op de noodzaak om tijdig een betrouwbaar beeld te krijgen van de mate waarin ook overheden de weg van verdere verfijning überhaupt willen inslaan. Daarbij dient bedacht te worden dat verfijning onlosmakelijk verbonden is met meer administratieve lasten waaronder de transparante borging van invoergegevens. 


\section{$4 \quad$ Discussie}

Met het hier beschreven rekeninstrument, heeft nu ook de akkerbouw- en vollegrondsgroentesector een rekeninstrument in handen waarmee het nutriëntenbeheer inzichtelijk kan worden gemaakt, waarmee verkend kan worden hoe de nutriëntenbenutting kan worden verbeterd, en waarmee milieuprestaties kunnen worden gekwantificeerd.

Dat betekent niet dat met dit rekeninstrument ieder denkbaar bedrijf kan worden doorgerekend. Tijdens het gebruik zal blijken dat het instrument bepaalde combinaties van grondsoorten, gewassen en mestsoorten niet aan kan zonder aanpassingen of uitbreidingen. Bedacht moet worden dat een KringloopWijzer ondanks de ambitie van bedrijfsspecificiteit, toch ook gebruik blijft maken van vele forfaits in de vorm van vaste getallen en rekenregels. Een zorgvuldig uitgevoerde test onder een, in eerste instantie, beperkte groep praktiserende telers met voldoende begeleiding is mede daarom noodzakelijk. De ervaring leert dat het 'management van verwachtingen' onder gebruikers daarbij heel veel aandacht verdient. Bij een bredere uitrol is het verder noodzakelijk dat de programmatuur van de KringloopWijzer naadloos aansluit bij bestaande managementpakketten. Alleen op die manier kan voorkomen worden dat telers hetzelfde soort informatie meerdere keren afzonderlijk moeten invoeren. Aan de omzetting van het bestaande Excel MS programma wordt dan ook gewerkt. 


\section{Literatuur}

Schröder, J.J., J.J. de Haan en J.R. van der Schoot, 2014. Meststofgebruiksruimte in relatie tot opbrengstniveaus, mestsoort en rijenbemesting. PPO publicatie 638, Wageningen UR, 44 pp.

Schröder, J.J., 2017. Inventarisatie van kansrijke equivalente maatregelen. Rapport WPR 682. Wageningen UR / Brancheorganisatie Akkerbouw, 's-Gravenhage, 27 pp.

Schröder, J.J., L.B. Šebek, J. Oenema, J.G. Conijn \& J. de Boer, 2018. Rekenregels van de KringloopWijzer 2017; achtergronden van BEX, BEA, BEN, BEP en BEC: actualisatie van de 2016 versie. PSG rapport 790, Wageningen UR, 101 pp. 
Correspondentie adres voor dit rapport: Postbus 16

6700 AA Wageningen

T 0317480700

www.wur.nl/plant-research

Rapport WPR-797
De missie van Wageningen University \& Research is 'To explore the potential of nature to improve the quality of life'. Binnen Wageningen University \& Research bundelen Wageningen University en gespecialiseerde onderzoeksinstituten van Stichting Wageningen Research hun krachten om bij te dragen aan de oplossing van belangrijke vragen in het domein van gezonde voeding en leefomgeving. Met ongeveer 30 vestigingen, 5.000 medewerkers en 10.000 studenten behoort Wageningen University \& Research wereldwijd tot de aansprekende kennisinstellingen binnen haar domein. De integrale benadering van de vraagstukken en de samenwerking tussen verschillende disciplines vormen het hart van de unieke Wageningen aanpak. 



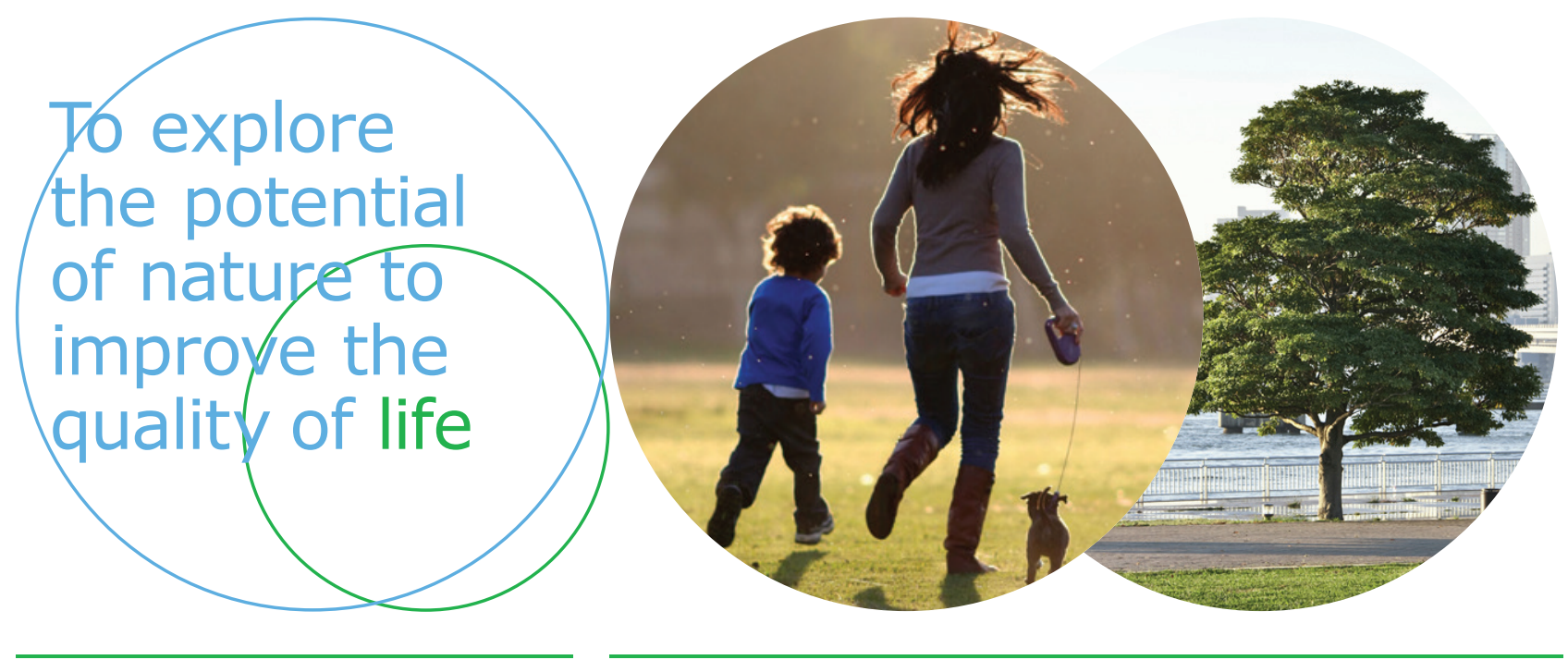

Corresponding address for this report: Postbus 16

6700 AA Wageningen

T 0317480700

www.wur.nl/plant-research

Rapport WPR-797
De missie van Wageningen University \& Research is 'To explore the potential of nature to improve the quality of life'. Binnen Wageningen University \& Research bundelen Wageningen University en gespecialiseerde onderzoeksinstituten van Stichting Wageningen Research hun krachten om bij te dragen aan de oplossing van belangrijke vragen in het domein van gezonde voeding en leefomgeving. Met ongeveer 30 vestigingen, 5.000 medewerkers en 10.000 studenten behoort Wageningen University \& Research wereldwijd tot de aansprekende kennisinstellingen binnen haar domein. De integrale benadering van de vraagstukken en de samenwerking tussen verschillende disciplines vormen het hart van de unieke Wageningen aanpak. 